\title{
A huge Pott's puffy tumour secondary to pansinusitis
}

\author{
Keli Dusu, ${ }^{1}$ Deepak Chandrasekharan, ${ }^{2}$ Chadwan Al Yaghchi, ${ }^{3}$ Robert Quiney ${ }^{2}$
}

${ }^{1}$ Head and Neck Surgery, University College London Hospitals NHS Foundation Trust, London, UK

${ }^{2}$ ENT, Royal National Throat Nose and Ear Hospital, London, UK

${ }^{3}$ ENT, Charing Cross Hospital, London, UK

\section{Correspondence to} Dr Keli Dusu,

kfdusu@hotmail.com

Accepted 19 March 2019

\section{DESCRIPTION}

A 36-year-old man presented with a 2-week history of a progressive forehead swelling and a frontal headache. He had no visual or neurological symptoms and there was no history of trauma. However, he reported a 4-week history of nasal obstruction with purulent nasal discharge.

On examination, there was a $15 \times 6 \mathrm{~cm}$ erythematous, fluctuant forehead swelling. Naso-endoscopy demonstrated purulent discharge bilaterally from the middle meati. A CT scan of the brain and paranasal sinuses demonstrated acute pansinusitis, osteomyelitis of the frontal bone with an associated subperiosteal abscess and an extradural abscess (figures 1 and 2). This is known as a Pott's puffy tumour, named after Sir Percival Pott and is a rare complication of frontal sinusitis. ${ }^{1}$

The patient underwent emergency endoscopic drainage of the sinuses and drainage of the frontal abscess via an external left eyebrow incision. Two hundred millilitres of pus was drained. He completed a 4-week course of intravenous ceftriaxone, $2 \mathrm{~g}$ once a day, and saline nasal irrigation three times a day. This was administered alongside a 2-week course of betamethasone sodium phosphate nasal drops, two drops twice a day in both nostrils. Serial post-operative CT imaging after 7, 12 and 20 days demonstrated resolution of the frontal abscess and an improvement of the extradural abscess.

Pott's puffy tumour occurs as a result of infection spreading via the venous drainage of the

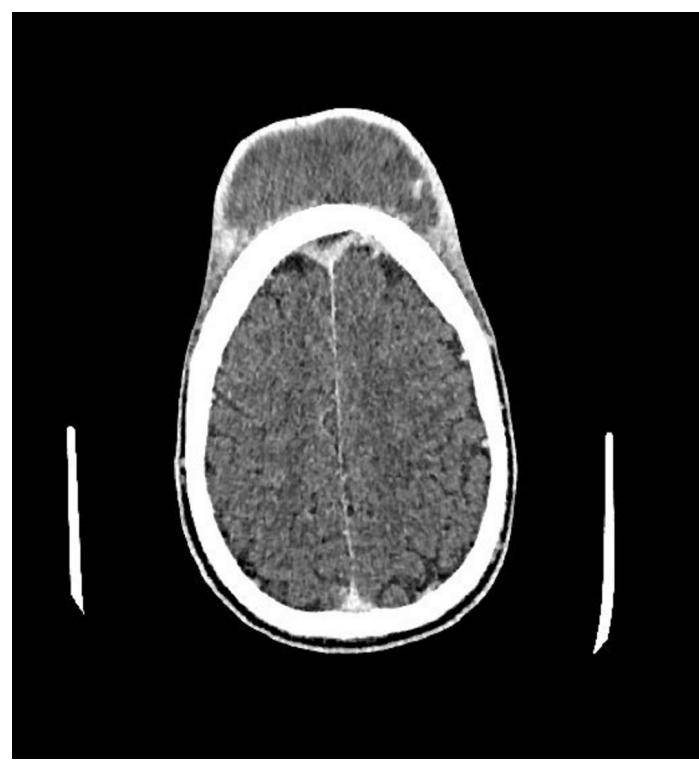

Figure 1 Axial CT demonstrating the large subperiosteal abscess of the frontal bone and the extradural abscess.

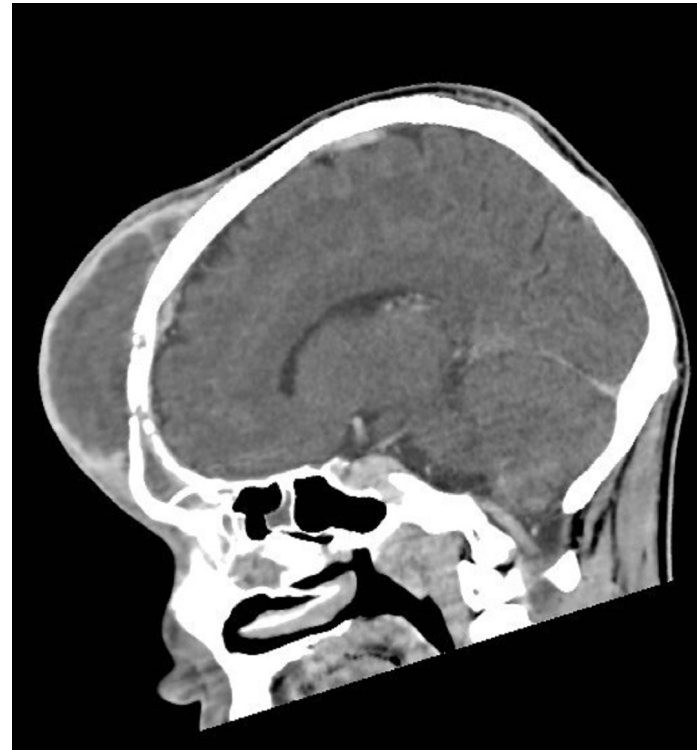

Figure 2 Sagittal CT demonstrating the large subperiosteal abscess of the frontal bone and the extradural abscess.

frontal sinus or from direct extension of the infection through the bone, resulting in osteomyelitis of the frontal bone and formation of subperiosteal abscesses. ${ }^{2}$ It is more commonly associated with the adolescent age group and is rarely seen in adults. ${ }^{3}$ Pott's puffy tumour is a risk factor for intracranial complications such as extradural abscess, subdural empyema and intracerebral abscess. These sequelae

\section{Patient's perspective}

I cannot commend the hospital highly enough for the swift and thorough care that I received, thank you!

\section{Learning points}

- Pott's puffy tumour is a rare complication of frontal sinusitis.

- Pott's puffy tumour is a significant risk factor for a range of intracranial complication secondary to thrombophlebitis of valveless diploic veins or direct spread from osteomyelitis of the posterior wall of the frontal sinus.

- Once a diagnosis of Pott's puffy tumour is suspected, prompt and serial cross-sectional imaging (CT or MRI) should be performed to evaluate for intracranial complications which may be asymptomatic. 
have been observed in 60\%-85\% of patients with Pott's puffy tumour. $^{4} 5$ Moreover, intracranial complications are often asymptomatic in the early stages, particularly when the abscess is localised in an area of the cortex where overt neurological signs are minimal. ${ }^{6}$ Pott's puffy tumour usually requires prompt surgical drainage in addition to prolonged antibiotic therapy. The goal of surgery is to drain the sinus, remove infected bone or granulation tissue and ventilate the frontal sinus. ${ }^{7}$ An external fronto-ethmoidectomy has been performed historically, however with advancement in technology, intranasal endoscopic sinus surgery in addition to percutaneous drainage has been performed with positive results. ${ }^{6}$

Contributors KD: literature review and preparation of manuscript. DC and CAY: manuscript review and revisions. RQ: revision and supervision of manuscript.

Funding The authors have not declared a specific grant for this research from any funding agency in the public, commercial or not-for-profit sectors.

Competing interests None declared.
Patient consent for publication Not required.

Provenance and peer review Not commissioned; externally peer reviewed.

\section{REFERENCES}

1 Vanderveken OM, De Smet K, Dogan-Duyar S, et al. Pott's puffy tumor in a 5-year-old boy: the role of ultrasound and contrast-enhanced CT imaging — Surgical case report. Int J Pediatr Otorhinolaryngol Extra 2012;7:1-5.

2 Goldberg AN, Oroszlan G, Anderson TD. Complications of frontal sinusitis and their management. Otolaryngol Clin North Am 2001;34:211-25.

3 Karaman E, Hacizade Y, Isildak H, et al. Pott's puffy tumor. J Craniofac Surg 2008;19:1694-7.

4 Rao M, Steele RW, Ward KJ. A "hickey". Epidural brain abscess, osteomyelitis of the frontal bone, and subcutaneous abscess (pott puffy tumor). Clin Pediatr 2003;42:657-60

5 Ibarra S, Aguirrebengoa K, Pomposo I, et al. [Osteomyelitis of the frontal bone (pott's puffy tumor). A report of 5 patients]. Enferm Infecc Microbiol Clin 1999;17:489-92.

6 Ketenci I, Unlü Y, Tucer B, et al. The Pott's puffy tumor: a dangerous sign for intracranial complications. Eur Arch Otorhinolaryngol 2011;268:1755-63.

7 Akiyama K, Karaki M, Mori N. Evaluation of adult pott's puffy tumor: our five cases and 27 literature cases. Laryngoscope 2012;122:2382-8.

Copyright 2019 BMJ Publishing Group. All rights reserved. For permission to reuse any of this content visit https://www.bmj.com/company/products-services/rights-and-licensing/permissions/

BMJ Case Report Fellows may re-use this article for personal use and teaching without any further permission.

Become a Fellow of BMJ Case Reports today and you can:

- Submit as many cases as you like

- Enjoy fast sympathetic peer review and rapid publication of accepted articles

- Access all the published articles

- Re-use any of the published material for personal use and teaching without further permission

For information on Institutional Fellowships contact consortiasales@bmjgroup.com

Visit casereports.bmj.com for more articles like this and to become a Fellow 